\title{
Cariogenicity of original and fruit juice-added soy beverages
}

\section{Cariogenicidade de bebidas de soja originais e acrescidas de sucos de fruta}

\section{Abstract}

Purpose: To evaluate the cariogenic potential of soy-based drinks available in the Brazilian market.

Methods: Three soy-based beverages from different trademarks (Ades ${ }^{\circledR}$, Mais Vita ${ }^{\circledR}$ and Sollys ${ }^{\circledR}$ ) were evaluated. For each brand, 04 flavors were analyzed (original, pineapple, orange and grape juices). Total Soluble Solid Content (TSSC), Reducing Sugars (RS), Non-reducing Sugars (NRS) and Total Sugars (TS) contents were assessed. Analyses were performed in triplicate. Data gathered underwent analysis of variance (ANOVA), and type I error $(\alpha)$ was set at 0.05 .

Results: TSSC values ranged between 8.25 and $15.00{ }^{\circ}$ Brix for all samples. There were no differences in TSSC levels between original and fruit juice-added soy drinks. RS have not been detected in any of the original soy beverages. Concerning to the drinks containing fruit juices, Mais Vita ${ }^{\circledR}$ grape significantly revealed the highest RS levels $(P<0.05)$. For NRS and TS, analyses indicated $A_{d e s}{ }^{\circledR}$ and Mais Vita ${ }^{\circledR}$ original contain levels significantly $(P<0.05)$ lower than the corresponding fruit juice-added drinks.

Conclusion: There is no difference in TSSC values between original and fruit juice-added soy drinks and most beverages containing fruit-juices presented higher levels of TS and sucrose when compared to the original soy drink, what might lead to an increased cariogenic potential.

Key words: Diet; cariogenic; sucrose; beverages; viscosity

\section{Resumo}

Objetivo: Avaliar o potencial cariogênico de bebidas à base de soja disponíveis no mercado brasileiro.

Metodologia: Três bebidas de soja de diferentes marcas comerciais $\left(\right.$ Ades $^{\circledR}$, Mais Vita ${ }^{\circledR}$ e Sollys ${ }^{\circledR}$ ) e sabores (original, abacaxi, laranja e uva) foram analisadas. Verificaram-se os Teores de Sólidos Solúveis Totais (TSST) e de Açúcares Redutores (AR), Não-redutores (ANR) e Totais (AT). As análises foram realizadas em triplicata e os dados submetidos à Análise de Variância (ANOVA), com erro $\alpha$ de 0,05.

Resultados: Os valores TSST variaram de 8,25 a 15,00 ${ }^{\circ}$ Brix para todas as amostras, não havendo diferenças entre as bebidas originais e as acrescidas de sucos de fruta. Não foram detectados AR nas amostras de bebidas originais. Quanto às formulações contendo sucos de fruta, o Mais Vita ${ }^{\circledR}$ uva apresentou os mais altos níveis de AR $(P<0,05)$. Quanto à ANR e AT, Ades ${ }^{\circledR}$ e Mais Vita ${ }^{\circledR}$ Originais revelaram teores significantemente menores que as bebidas acrescidas de sucos de fruta $(P<0,05)$

Conclusão: Não houve diferença no TSST entre as bebidas de soja originais e as acrescidas de sucos de fruta. A maioria das formulações contendo suco de fruta apresentou teores mais altos de AT e sacarose quando comparados à respectiva bebida original, o que pode resultar em um maior potencial cariogênico do produto.

Palavras-chave: Dieta; cariogênicos; sacarose; bebidas; viscosidade

\author{
Gisely Maria Freire Abílio a \\ Diego Isaias Dias Marques a \\ Irlan de Almeida Freires b \\ Alessandro Leite Cavalcantic \\ Ricardo Dias de Castro d
}

a Federal University of Paraiba, Bananeiras, PB, Brazil

b School of Dentistry, Federal University of Paraiba, João Pessoa, PB, Brazil

c Department of Dentistry, School of Dentistry, State University of Paraiba, Campina Grande, PB, Brazil

dDepartment of Clinics and Social Dentistry, School of Dentistry, Federal University of Paraiba, João Pessoa, PB, Brazil

Correspondence:

Ricardo Dias de Castro

Rua Cajazeiras, 475/Apt. 102 - Manaira

João Pessoa, PB - Brasil

58038-040

E-mail: ricardodiasdecastro@yahoo.com.br

Received: September 22, 201

Accepted: November 19, 2011

Conflict of Interests: The authors state that there are no financial and personal conflicts of interest that could have inappropriately influenced their work.

Copyright: (c) 2011 Abílio et al.; licensee EDIPUCRS This is an Open Access article distributed under the terms of the Creative Commons AttributionNoncommercial-No Derivative Works 3.0 Unported License. 


\section{Introduction}

The search for more nutritious and healthier foods has been demonstrated by a significant amount of the population, which is driven to have a calorie restricted, lower fat and cholesterol-free diet (1), either for medical, philosophical or social reasons $(1,2)$. In this context, soy and its derivatives emerge as a valuable alternative for supplying such sort of demand (1).

Soy contains $40 \%$ high quality and low cost protein, $20 \%$ fat, rich in polyunsaturated fatty acids, and a considerable content of vitamins and minerals, factors that relate this grain consumption to risk reduction of developing many chronic diseases, including breast and prostate cancers, osteoporosis and coronary heart diseases (1).

In the last years, the non-alcoholic drinks market has been developing rather diversified products which follow a trend of appreciation of attributes regarding nutritional quality (3). Tropical fruits-based soy drinks are perfectly portrayed in such a context, once they may combine both characteristics of flavor and vitamins present in fruits with phytochemicals from soy (4).

Nevertheless, the addition of fruit juices to soy beverages is thought to cause damage to teeth because of two properties: first of all, the low $\mathrm{pH}$ and high titratable acidity of some drinks can cause erosion on enamel surface (5), and secondly the fermentable carbohydrates in the drinks are metabolized by plaque microrganisms to generate organic acids in the dental plaque that can cause demineralization, leading to dental caries $(6,7)$.

As regards that cariogenicity, sucrose, glucose and fructose found in fruit juice-added drinks are probably the main sugars associated with infant caries (6). Sucrose, the most widely used sugar $(6,7)$, is considered to be the most important one in dental caries as it is the only substrate used for bacterial generation of plaque dextrans which is essential for bacterial adherence, and thus facilitates the implantation of cariogenic bacteria in the oral cavity (6).

The Total Soluble Solids Content (TSSC) or degrees Brix $\left({ }^{\circ} \mathrm{Bx}\right)$ is numerically equal to the percentage of sugar and other dissolved solids in a solution. This scale is used in the food industry for measuring the approximate amount of sugars in fruit juices and others beverages. Then, a solution that is 25 degrees Brix has $25 \mathrm{~g}$ of sugar per $100 \mathrm{~g}$ of solution (8).

In a general way, sugars may be classified as reducing or non-reducing based on their reactivity with Fehling's reagents. Sugars that contain aldehyde groups that are oxidized to carboxylic acids are classified as reducing sugars (e.g. glucose, fructose, maltose, lactose) $(5,9)$. Those that are unable to reduce the above oxidizing agents are called nonreducing sugars (e.g.: sucrose). Fruit juices are examples of foods that contain a mixture of these three soluble sugars (fructose, sucrose and glucose) $(5,10)$, with the concentration varying according to the type and maturation status of the fruit. Once more, such sugariness, coupled with an acidic nature, has caused fruit juice to be cited as a risk factor to dental decay (5).
Hence, in view of the great importance of knowing the cariogenicity of those kinds of beverages, commonly drunk by children, this study aimed to evaluate the cariogenic potential of soy-based drinks of different brands containing pineapple, orange and grape juices commercially available in the Brazilian market, establishing parameters for comparison with the respective soy milks.

\section{Methods}

Analysis of physicochemical parameters of the soy juices was performed in the Chemistry Laboratory, Department of Basic and Social Sciences; Center for Human, Social and Agrarian Sciences; Federal University of Paraiba.

Three soy-based beverages from different trademarks were evaluated. For each brand, were analyzed flavors of pineapple, orange, grape, and original, making a total of 12 samples (Table 1).

Table 1. Soy-based beverages under evaluation according to brand name, flavor and manufacturer.

\begin{tabular}{lll}
\hline \multicolumn{1}{c}{ Brand Name } & \multicolumn{1}{c}{ Flavor } & \multicolumn{1}{c}{ Manufacturer } \\
\hline Ades $^{\circledR}$ & Orange & Unilever Brasil Alimentos Ltd. \\
& Grape & Unilever Brasil Alimentos Ltd. \\
& Pineapple & Unilever Brasil Alimentos Ltd. \\
& Original & Unilever Brasil Alimentos Ltd. \\
Mais Vita ${ }^{\circledR}$ & Orange & Yoki Alimentos Ltd. \\
& Grape & Yoki Alimentos Ltd. \\
& Pineapple & Yoki Alimentos Ltd. \\
& Original & Yoki Alimentos Ltd. \\
Sollys ${ }^{\circledR}$ & Orange & Nestlé Brasil Ltd. \\
& Grape & Nestlé Brasil Ltd. \\
& Pineapple & Nestlé Brasil Ltd. \\
& Original & Nestlé Brasil Ltd. \\
\hline
\end{tabular}

Samples were obtained at different retail establishments from the city of Campina Grande, Paraiba, Brazil. Chemical and physicochemical analyses were performed in triplicate. The Samples, packed in original cartons containing $250 \mathrm{~mL}$ and $1000 \mathrm{~mL}$, were coded and kept at room temperature until the time of analysis.

Parameters determination of TSSC, reducing sugars, nonreducing sugars and total sugars was undertaken according to methodology described by the Adolf Lutz Institute (11).

Degrees Brix ( $\left.{ }^{\circ} \mathrm{Bx}\right)$

This test assesses the total soluble solids content (proteins, lipids, glucides, mineral salts, vitamins, organic acids, pigments and other substances) in a sample. The ${ }^{\circ} \mathrm{Bx}$ readings were made by refractometry using an Abbe refractometer (PZO-RL1, Warsaw, Poland). As the refractive index of a sugar-containing solution is also temperaturedependent, refractometers are typically calibrated at $20^{\circ} \mathrm{C}$. The equipment was calibrated with deionized water 
(refraction index $=1.3330$ and $0^{\circ}$ Brix at $20^{\circ} \mathrm{C}$ ) and the readings of the samples were performed (12).

Reducing sugars, non-reducing sugars and total sugars

Reducing sugars (e.g.: glucose), non-reducing sugars (e.g.: sucrose) and total sugars were measured according to the method adopted by the Association of Official Analytical Chemists (13), and results were expressed as g/100 mL.

\section{Statistical analysis}

Data gathered were statistically treated by means of Analysis of Variance test (ANOVA), and type I error (alpha) was set at 0.05 . Such analysis was performed by using the statistical program Graphpad Prism 5.0.

\section{Results}

The results of chemical and physicochemical properties of total soluble solids ( $\left.{ }^{\circ} \mathrm{Brix}\right)$, reducing sugars, non-reducing sugars and total sugars are disposed in Table 2.

Regarding the parameter of total soluble solids content, values ranged between 8.25 and $15.00^{\circ}$ Brix for all samples under evaluation. Statistical analysis of these data indicated that Ades ${ }^{\circledR}$ values are significantly $(P<0.05)$ lower than Sollys ${ }^{\circledR}$ values and that for the 03 brands tested no statistical differences were found between the respective levels of TSSC for original and fruit juice-added soy drinks.

According to the method used, reducing sugars have not been detected in any of the original soy beverages samples. With regards to the drinks containing fruit juices, Sollys ${ }^{\circledR}$ pineapple flavor was found to show reducing sugars values ( $0.75 \mathrm{~g}$ glucose per $100 \mathrm{~mL}$ sample) statistically lower than all the others $(P<0.05)$, whereas Mais Vita ${ }^{\circledR}$ grape flavor significantly revealed $(P<0.05)$ the highest reducing sugars levels (3.95 g glucose per $100 \mathrm{~mL}$ sample).
For total sugars and non-reducing sugars, analyses indicated that the brands Ades ${ }^{\circledR}$ and Mais Vita ${ }^{\circledR}$ contain in their original flavor levels significantly $(P<0.05)$ lower than the corresponding fruit juice-added drinks.

\section{Discussion}

Dental caries is initiated by the process of fermentation, in which the production of strong organic acids causes demineralization of the tooth surface (14). Stephan in his classic studies in the early 1940's showed that dental plaque exposed to sucrose could rapidly produce acids, causing a rapid drop in $\mathrm{pH}$ followed by a gradual recovery toward the baseline plaque $\mathrm{pH}(15)$. Since that time, a causal association between the production of strong acids from plaque in response to sucrose and caries activity has become well established. Therefore, limitation of sucrose intake is an important lifestyle change to promote in patients with high caries risk/activity (7).

The study on cariogenicity of everyday products such as fruit juice beverages (which include sucrose) has been gaining significant importance in view of outlining consumers' caries risk.

The present investigation has assessed not only the TSSC (Degrees ${ }^{\circ} \mathrm{Bx}$ ), which shows a direct relationship with the viscosity of the ingested foods, possibly facilitating the retention of diet components onto dental surfaces, but also the presence of sugars (especially sucrose) in the products compositions.

In this study, TSSC ( ${ }^{\circ}$ Brix values) ranged from 8.25 ${ }^{\circ}$ Brix (Grape juice, $\operatorname{Ades}^{\circledR}$ ) to $15.00{ }^{\circ}$ Brix (Grape juice, Mais Vita $^{\circledR}$ ), which is in agreement with the findings of previous Brazilian studies $(5,16)$. Regarding this parameter, there was no statistically significant difference between original soy and fruit juice-added drinks for all three brands assessed.

Table 2. Chemical and physicochemical parameters evaluated for soy-based beverages samples.

\begin{tabular}{|c|c|c|c|c|c|}
\hline Sample & Flavor & TSSC ( ${ }^{\circ}$ Brix) & $\begin{array}{l}\text { Reducing sugar } \\
\text { ( } \mathrm{g} \text { of glucose/ } \\
100 \mathrm{~mL} \text { of sample) }\end{array}$ & $\begin{array}{c}\text { Non-reducing sugar } \\
\text { (g of sucrose/ } \\
100 \mathrm{~mL} \text { of sample) }\end{array}$ & $\begin{array}{c}\text { Total sugar } \\
\text { ( } \mathrm{g} \text { of sugar/ } \\
100 \mathrm{~mL} \text { of sample) }\end{array}$ \\
\hline \multirow[t]{4}{*}{$\operatorname{Ades}^{\circledR}$} & Orange & $8.50 \pm 0.50^{a}$ & $1.63 \pm 0.05^{b c}$ & $3.90 \pm 0.06^{c}$ & $5.75 \pm 0.12^{d}$ \\
\hline & Grape & $8.25 \pm 0.70^{a}$ & $1.76 \pm 0.03^{c}$ & $4.63 \pm 0.05^{d}$ & $6.63 \pm 0.04 \mathrm{e}$ \\
\hline & Pineapple & $9.25 \pm 0.00^{a}$ & $1.70 \pm 0.03^{b c}$ & $10.18 \pm 0.30^{h}$ & $12.42 \pm 0.299$ \\
\hline & Original & $8.50 \pm 0.20 a$ & 0,00 & $2.94 \pm 0.01^{\circ}$ & $3.10 \pm 0.01^{a}$ \\
\hline \multirow[t]{4}{*}{ Mais Vita ${ }^{\circledR}$} & Orange & $12.25 \pm 0.70^{b}$ & $1.97 \pm 0.08^{d}$ & $8.97 \pm 0.17 \mathrm{~g}$ & $11.41 \pm 0.24^{f}$ \\
\hline & Grape & $15.00 \pm 0.50^{c}$ & $3.95 \pm 0.15^{f}$ & $7.36 \pm 0.22^{f}$ & $11.70 \pm 0.26^{f}$ \\
\hline & Pineapple & $12.50 \pm 0.50^{b}$ & $3.23 \pm 0.14 \mathrm{e}$ & $7.71 \pm 0.10^{f}$ & $11.36 \pm 0.05^{f}$ \\
\hline & Original & $10.00 \pm 0.30 \mathrm{ab}$ & 0,00 & $4.13 \pm 0.01^{c}$ & $4.35 \pm 0.01^{b}$ \\
\hline \multirow[t]{4}{*}{ Sollys ${ }^{\circledR}$} & Orange & $11.75 \pm 0.50^{b}$ & $1.56 \pm 0.01^{b}$ & $3.33 \pm 0.02^{b}$ & $5.07 \pm 0.03^{c}$ \\
\hline & Grape & $11.50 \pm 0.20^{b}$ & $1.97 \pm 0.01^{\mathrm{d}}$ & $3.13 \pm 0.11^{\mathrm{ab}}$ & $5.26 \pm 0.12^{c}$ \\
\hline & Pineapple & $11.25 \pm 0.60^{b}$ & $0.75 \pm 0.01^{a}$ & $3.45 \pm 0.13^{b}$ & $4.38 \pm 0.14^{b}$ \\
\hline & Original & $10.25 \pm 0.00^{b}$ & 0,00 & $5.19 \pm 0.09 \mathrm{e}$ & $5.46 \pm 0.12^{\mathrm{cd}}$ \\
\hline
\end{tabular}

This table presents averages of the triplicates ( \pm standard deviation). Different letters in the same column indicate statistically significant differences $(P<0.05)$ according to ANOVA test. 
A cohort study in USA conducted by Marshall et al. (17) investigated for 4 years association between caries experience and intake of sugared beverages in children at 4 to 7 years of age. Authors found that consumption of regular soda pop, regular powdered beverages, and, to a lesser extent, $100 \%$ juice in early childhood was associated with increased caries risk. The present study assessed the cariogenic potential of soy-based drinks and found that juice-added beverages lead to an increased caries risk.

The cariogenic potential of foods is linked to the content of a variety of sugars, monosaccharides and disaccharides (18). Sucrose, glucose and fructose, are fermentable to acid by a variety of oral microorganisms (19), and sucrose can be split into its two component sugars (glucose and fructose) (20).

This study verified the existence and quantity of total, reducing (e.g. glucose) and non-reducing (e.g. sucrose) sugars added to Brazilian soy-based drinks formulations. More than $30 \%$ of the samples presented total sugar content over $10 \mathrm{~g}$ per $100 \mathrm{~mL}$, which is an important value as far as liquid intake by children is concerned.

A recent study evaluated the total sugar content of popular beverages from Syria, including orange juice, cola and full-fat milk. It was verified that, besides being acid (pH 3.10) the orange juice sample examined had a total sugar content of $11.57 \mathrm{~g} / 100 \mathrm{~mL}$ (21). Such value can be compared to what has been found in Mais Vita ${ }^{\circledR}$ orange flavor $(11.41 \pm 0.24 \mathrm{~g} / 100 \mathrm{~mL})$.

Abreu et al. (4) agree with the results obtained in the present study and point out that the greatest amount of sugars in mixed drinks has been due both to incorporation of sugars from the added juice and to addition of sugars in the drink formulation.

A study evaluating the effect of milk and soy-based infant formulas and sucrose association on demineralization of primary enamel and dental biofilm formed showed that both formulas induced significant enamel mineral loss, which increased when sucrose was added. Moreover, both formulas were fermented, resulting in a decrease of biofilm $\mathrm{pH}$, irrespective of sucrose addition (22).

The cariogenic and erosive potential of some industrialized fruit juices available in Brazil was recently investigated in the study by Almeida et al. (5). Most juices presented low $\mathrm{pH}$ and a high total sugar content.
Besides cariogenicity, other aspects related to the drinks are needed to be assessed such as acidity. A previous study investigated the erosive potential of the same soy-based drinks used in this study. Were included tests to verify endogenous $\mathrm{pH}$ and titratable acidity. Results indicated that all soy-based juices showed $\mathrm{pH}$ below the critical value of 5.5 (23).

National and international literature is scarce in studies investigating the presence of reducing, non-reducing and total sugars in industrialized fruit juices $(4,5,21)$. In addition, to the best of our knowledge, there is no standardized value in the literature to establish the cariogenic potential of the sugars present in beverages (5).

Better labelling of drinks which disclosed the actual concentration (percentage by weight or volume) of sucrose and other sugars would help consumers in choosing products which would be less likely to contribute to dental caries (24).

Besides that, a further issue to be considered is the use of sweeteners in the beverages to reduce the intake of sucrose and other fermentable sugars. A number of sweeteners now exist which are effective replacements for dietary sucrose. Materials such as sucralose, leucrose, trehalose, palatinose and isomalt (which are chemically similar to sucrose) are now being used in confectionery (25).

Given this, the use of sucrose substitutes might reduce the product cariogenicity at the same time that might retain its pleasant taste. Health professionals and parents, principally, should be aware of the damages some fruit juice-added beverages might cause to tooth structures. Accordingly, it has been important knowing their cariogenic and acidogenic potentials in order to reach safer patterns of consumption.

\section{Conclusions}

According to the methods employed and from the results obtained, it has been valid considering that:

- As regards total soluble solids content, there is no difference between original and fruit juice-added soy drinks.

- Excepting the brand Sollys ${ }^{\circledR}$, fruit juice-added beverages presented higher levels of total sugars and sucrose when compared to the original soy drink, what might lead to an increased cariogenic potential. and Brazil nuts beverage: physicochemical, nutritional and consumer acceptance. Alim Nutr 2004;15:163-74.

2. Story M, Kaphingst KM, Robinson-O'Brien R, Glanz K. Creating healthy food and eating environments: policy and environmental approaches. Annu Rev Public Health 2008;29:253-72.

3. Bates RP, Morris JR, Crandall PG. Principles and practices of small - and medium - scale fruit juice processing. Florida: University of Florida, Food Science and Human Nutrition Department, 2001. (FAO Agricultural Services Bulletin, 146). Available from: http://www. fao.org/DOCREP/005/Y2515E/y2515e00.htm\#toc. 
4. Abreu CRA, Pinheiro AM, Maia GA, Carvalho JM, Sousa PHM. Chemical and physicochemical evaluation of soybean beverages added tropical fruits. Alim Nutr 2007; 18:291-6.

5. Almeida LFD, Abílio GMF, Cavalcante MT, Castro RD, Cavalcanti AL. Cariogenic and erosive potential of industrialized fruit juices available in Brazil. Braz J Oral Sci 2010;9:351-7.

6. Mikkelsen L. Effect of sucrose intake on number of bacteria in plaque expressing extracellular carbohydrate metabolizing enzyme. Caries Res 1996;30:65-70.

7. Walsh LJ. Dental plaque fermentation and its role in caries risk assessment. Int Dent 2010;8:34-40.

8. Cavalcanti AL, Costa Oliveira M, Florentino VG, dos Santos JA, Vieira FF, Cavalcanti CL. Short communication: In vitro assessment of erosive potential of energy drinks. Eur Arch Paediatr Dent 2010;11:253-5.

9. Bornet FRI. Undigestible sugars in food products. Am J Clin Nutr 1994;59:763-9.

10. Birkhed D. Sugar content, acidity and effect on plaque $\mathrm{pH}$ of fruit juices, fruit drinks, carbonated beverages and sport drinks. Caries Res 1984;18:120-7.

11. Adolfo Lutz Institute. Analytic norms of the Adolfo Lutz Institute. Chemical and physical methods for food analysis. $3^{\text {rd }}$. ed. São Paulo: IMESP; 1985.

12. Cavalcanti AL, Oliveira OS, Evangelista APA, Vieira FF, Granville-Garcia AF, Cavalcanti $\mathrm{CL}$. pH and total soluble solid content in concentrated and diluted in natura tropical fruit juices. Acta Stomatol Croat 2008;42:229-34.

13. Association of Official Analytical Chemists. Official Methods of Analysis. $16^{\text {th }}$ ed. Arlington: AOAC; 1995.

14. Fejerskov $O$, Thylstrup A, Larsen MJ. Rational use of fluorides in caries prevention: A concept based on possible cariostatic mechanisms. Acta Odontol Scand 1981;39:241-9.

15. Stephan RM. Intra-oral hydrogen ion concentrations associated with dental caries activity. J Dent Res 1944;23:257-66.

16. Cavalcanti AL, Oliveira KF, Paiva PS, Rabelo MVD, Costa SKP, Vieira FF. Determination of total soluble solids ( ${ }^{\circ}$ Brix) and $\mathrm{pH}$ in milk drinks and industrialized fruit juices. Pesq Bras Odontoped Clin Integr 2006;6:57-64

17. Marshall TA, Levy SM, Broffitt B, Warren JJ, Eichenberger-Gilmore JM, Burns TL, Stumbo PJ. Dental caries and beverage consumption in young children. Pediatr 2003;1 12:184-91.

18. Committee on Nutrition. American Academy of Pediatrics: The use and misuse of fruit juice in pediatrics. Pediatr 2001;107:1210-3.

19. Grenby TH, Mistry M, Desai T. Potential dental effects of infants' fruit drinks studied in vitro. Br J Nutr 1990; 64:273-83.

20. Demiate IM, Wosiacki G, Czelusniak C, Nogueira A. Analysis of total and reducing sugar in foods. A comparative study between colorimetric and titration techniques. Agrarian Sci Eng 2002;8:65-78.

21. Saeed S, Al-Tinawi M. Evaluation of acidity and total sugar content of children's popular beverages and their effect on plaque $\mathrm{pH}$. J Indian Soc Pedod Prev Dent 2010;28: 189-92.

22. Papa M, Cia AM, Tabchoury COM, Del Bel Cury AA, Tenuta LMA, Arthur RA et al. Effect of milk and soy-based infant formulas on in situ demineralization of human primary enamel. Pediatr Dent 2010;32:35-40

23. Silva TAA, Sampaio CS, Furtado JEAS, Abílio GMF, Xavier AFC, Cavalcanti AL. Evaluation of erosive potential of soy-based drinks. RBCS 2010;14:109-14.

24. Newbrun E. Sucrose in the dynamics of the carious process. Int Dent J 1982;32:13-23.

25. Peltroche-Llacsahuanga H, Hauk CJ, Kock R, Lampert F, Lutticken R, Haagse G. Assessment of acid production by various human oral microorganisms when palatinose or leucrose is utilized. J Dent Res 2001;80:378-84. 